University at Buffalo School of Law

Digital Commons @ University at Buffalo School of Law

Fall 1-1-1992

\title{
The Daughters of Job: Property Rights and Women's Lives in Mid- Nineteenth-Century Massachusetts
}

\author{
Dianne Avery \\ University at Buffalo School of Law \\ Alfred S. Konefsky \\ University at Buffalo School of Law
}

Follow this and additional works at: https://digitalcommons.law.buffalo.edu/journal_articles

Part of the Civil Rights and Discrimination Commons, Gender and Sexuality Commons, and the Law and Gender Commons

\section{Recommended Citation}

Dianne Avery \& Alfred S. Konefsky, The Daughters of Job: Property Rights and Women's Lives in MidNineteenth-Century Massachusetts, 10 Law \& Hist. Rev. 323 (1992).

Available at: https://digitalcommons.law.buffalo.edu/journal_articles/816

This article has been published in a revised form in Law and History Review https://doi.org/10.2307/743764. This version is free to view and download for private research and study only. Not for re-distribution, re-sale or use in derivative works. (C) the $\mathrm{A}$

\section{IN COPYRIGHT}

This Article is brought to you for free and open access by the Faculty Scholarship at Digital Commons @ University at Buffalo School of Law. It has been accepted for inclusion in Journal Articles by an authorized administrator of Digital Commons @ University at Buffalo School of Law. For more information, please contact lawscholar@buffalo.edu. 


\title{
Notes and Documents
}

\section{The Daughters of Job: Property Rights and Women's Lives in Mid- Nineteenth-Century Massachusetts}

\author{
DIANNE AVERY and ALFRED S. KONEFSKY
}

Mix the lyric water

Of the movement that is song

With the sandy stuff of thought,

So that something may be wrought

Concrete from the flux of pain,

Some small monument remain

Of her, who was Job's own daughter

Unterrestrial and strong.

$$
\text { - Jean Starr Untermeyer }{ }^{1}
$$

Sometime in the winter of 1839 ; Keziah Kendall, a thirty-two-year-old woman living with her two sisters on a dairy farm "not many miles from Cambridge," heard from her "milkman" that a public lecture would be delivered on the legal rights of women. ${ }^{2}$ Kendall "thought

1. "Injunction," in J. UNTermeyer, JOB's Daughter 13 (1967). Excerpted from JOB'S DAUGHTER by Jean Untermeyer. Copyright ( 1967 by W. W. Norton \& Company, Inc. Reprinted with permission of the publisher, W. W. Norton \& Company.

2. Letter from Keziah Kendall to Simon Greenleaf (undated) (Box 3, Folder 10, Simon Greenleaf Papers, Harvard Law School Library) [hereinafter Kendall Letter]. The letter was probably written in the late winter or early spring of 1839 . This dating follows from internal evidence in the letter itself, as well as evidence described infra note 5 . The letter is reprinted in its entirety as a separate document immediately following this essay. Keziah Kendall spelled her name in two ways in the text of the letter. We have chosen to use the spelling that appears in her signature.

Dianne Avery and Alfred S. Konefsky are professors of law at the State University of New York at Buffalo. 
[she] would go and learn," but when she attended she found that she "did not like that lecture much." ${ }^{3}$ The speaker was Simon Greenleaf, Royall Professor of Law at Harvard University, ${ }^{4}$ who at the time was delivering lyceum lectures in eastern Massachusetts on the subject of women's rights. ${ }^{5}$ Not the least bit intimidated by Greenleaf's stature, Kendall wrote him a candid letter, expressing her disapproval of his talk: "[T]here was nothing in it but what every body knows. ... What I wanted to know, was good reasons" for the rules governing the legal rights of women "that I cant account for. I do hope if you are ever to lecture at the Lyceum again, that you will give us some." Kendall then proceeded to tell Professor Greenleaf the remarkable and poignant story of how her personal experiences had shaped her interest in her own legal rights.

Kendall's decision to recount her private tale to a stranger was set within the larger framework of the contemporaneous public furor in Boston over the political and legal rights of women. For almost a year during 1837 and 1838, the Grimké sisters of South Carolina toured eastern Massachusetts. ${ }^{7}$ As agents of the American Anti-Slavery Society, Sarah and Angelina Grimké gave numerous public lectures on the evils

3. Id.

4. Greenleaf (1783-1853) was appointed Royall Professor in 1833, after nearly thirty years of law practice in Maine. After Joseph Story's death in 1845, Greenleaf became Dane Professor of Law at Harvard, serving until his retirement in 1848.

5. Greenleaf lectured on "The Legal Rights of Women" at the Salem Lyceum during the 1838-39 season. H. Oliver, Historical Sketch of THe Salem LyCeum 43 (1879). It is not likely that Keziah Kendall, living "not many miles from Cambridge," would have traveled to Salem to hear this lecture. In her letter to Greenleaf, she mentions another lyceum lecture she "heard in C." There were many local lyceums in eastern Massachusetts, and Greenleaf could have appeared at any of them in addition to Salem. The "C." might refer to Cambridge, Charlestown, or Concord. The records of the Concord Lyceum for this period do not mention any lecture by Greenleaf. See K. Cameron, The Massachusetts Lyceum during THe American RenaissanCe 14755 (1969). Greenleaf did receive an invitation to speak at the Charlestown Lyceum in 1839. Letter from Charlestown Lyceum to Simon Greenleaf (Aug. 31, 1839) (Simon Greenleaf Papers, Harvard Law School Library, Box 3, Folder 3). No Cambridge Lyceum records have apparently survived.

6. Kendall Letter, supra note 2.

7. Sarah Grimké (1792-1873) and Angelina Grimké (1805-79), born into a wealthy slaveholding family in South Carolina, became noted abolitionists and feminists. See generally G. LERNER, THE GRIMKÉ SISTERS FROM SOUTH CAROLINA (1967). For a brief description of their Massachusetts tour, see THE Public Years of SARAH AND ANGelina GRIMKÉ: SELECTED WRITINGS, 1835-1839, at 135-41 (L. Ceplair ed. 1989) [hereinafter The Public YeARs]; for a more comprehensive account, see Melder, Forerunners of Freedom: The Grimké Sisters in Massachusetts, 1837-38, 103 EssEX INST. HIST. COLLECTIONS 223 (1967). 
of slavery. ${ }^{8}$ Not only did they defy religious and social norms as women speaking openly in churches and public places, but they also committed the heresy of speaking before mixed audiences of men and women. ${ }^{9}$ They compounded the heresy by making explicit links between slavery and the legal status of women. ${ }^{10}$ The Grimkés' focus on women's rights sharpened when Sarah Grimké began writing Letters on the Equality of the Sexes and the Condition of Woman, first published in serial form in 1837 and later, as a tract, in 1838. "In March and April 1838, the sisters delivered, in Boston, a controversial series of six lectures on the rights of women. ${ }^{12}$

As Keziah Kendall had reacted to Greenleaf, so too had Greenleaf reacted to the Grimké sisters. When he finally published his thoughts, "On the Legal Rights of Woman," in an anonymous essay in the June, 1840, issue of The Christian Review, ${ }^{13}$ he began with a hollow protest that his purpose was not "to enter into the controversy, in regard to the political and social relations of woman, which now agitates a portion of the community."'4 Greenleaf's choice of topic, however, was almost certainly motivated by a desire to counter the threatening ideas spread by the Grimkés. For, as he observed: "The public ear has been filled with declamation upon the wrongs of woman, - her political and legal non-existence, - her natural equality, - her inalienable rights, and her

8. Gerda Lerner estimates that, after having "been in New England twenty-three weeks, [the Grimkes] had spoken before at least eighty-eight meetings in sixty-seven towns. They had reached, face to face, a minimum of 40,500 people in meetings." G. LERNER, supra note 7, at 227.

9. Id. at 168-69; see also Melder, supra note 7, at 232.

10. See, e.g., infra text accompanying note 33. For discussion of the relationship between abolitionism and feminism, see B. Hersh, The Slavery of SeX: FeminIST-ABolitionists IN AMERICA (1978); DuBois, Women's Rights and Abolition: The Nature of the Connection, in ANTISLAVERY ReConsidered: New Perspectives on the ABOLITIONISTS 238 (L. Perry \& M. Fellman eds. 1979).

11. S. Grimké, Letters on the Equality of the Sexes and the Condition of Woman. Addressed to Mary S. Parker, President of the Boston female ANTI-SLAVERY SOCIETY (1838). The Letters are reprinted in S. GRIMKÉ, LeTTERS ON THE Equality of THE SeXes AND OTHER ESSAYs 31-103 (E. Bartlett ed. 1988) [hereinafter S. Grimké]. See also The PUBLIC YeARS, supra note 7, at 204-72. Larry Ceplair notes that the Letters were first published in the New England Spectator in a series beginning July 19,1837 , were subsequently reprinted in The Liberator in January and February of 1838 , and finally published as a single tract in 1838 by the Boston publisher, Isaac Knapp. Id. at $204 \mathrm{n}$.

12. See, e.g., The Public Years, supra note 7, at xvii, 301-2.

13. Greenleaf, 5 Christian Rev. 269 (1840). The manuscript of the article, in Greenleaf's handwriting, can be found in Box 24, Folder 5, Simon Greenleaf Papers, Harvard Law School Library.

14. Id. at 269. 
degrading servitude; as though the sex, at some early period, had been conquered and subjugated by man, and were still held in a state of bondage."'s Greenleaf would hear nothing of the legal "wrongs" of women: He believed, contrary to the Grimkés' arguments, that women were legally equal to men. On the other hand, Keziah Kendall could not understand how Greenleaf could conclude that there was legal equality between the sexes.

In the context of the property rights of married women in antebellum Massachusetts, Keziah Kendall's skepticism about Greenleaf's position was understandable. Under the common law, adult single women could own and convey property, write wills, sue and be sued, and enter into binding contracts. But upon marriage, a woman lost her legal identity and became a feme covert-a woman under the protection of her husband. As Greenleaf phrased the commonly held view of the concept of marital unity, "by marriage, the husband and wife become one person in law, her very legal existence being merged in his own."16 Although the husband was obligated to maintain his wife during marriage and became liable for all her debts, including those incurred prior to marriage, he also had nearly absolute authority over her person and property during coverture. This meant that a single woman who owned property could face substantial economic risks when she entered into a marriage. Her husband became the owner, outright, of all her personal property. Nominally the wife retained ownership of her real property because it could only be sold by joint deed and, if she survived her husband, was "at her disposal, as it was before the marriage."17 But during marriage, the husband was entitled to control and manage all her real property and to receive its rents and profits. Thus, the husband owned all the economic value of any property that a woman might bring to or acquire during marriage-stocks and bonds, bank accounts, houses, farms, carriages, cattle, and even wages. And, as Keziah Kendall knew too well, a husband's creditors could reach all the husband's interest in this property, even to satisfy his premarital debts.

Within the next fifteen or so years, Massachusetts, like a number of states, would reform these common law property rules through piecemeal legislation. ${ }^{18}$ Sarah Grimké's Letters and Simon Greenleaf's ly-

15. Id.

16. Id. at 279 .

17. Id. at 282 .

18. The two most significant Massachusetts statutes reforming married women's property rights were passed in 1845 and 1855 . The 1845 statute gave women the right to enter into written premarital agreements regarding their separate property, and to hold and manage that property after marriage without a trustee. 1845 Mass. Acts, ch. 
ceum lectures and his Christian Review article prefigured the public debates that produced the Married Women's Property Acts. ${ }^{19}$ Keziah Kendall's letter to Greenleaf revealed the private anguish of women whose choices in life were constrained by the old common law rules. To be sure, some women were able to circumvent the common law and secure some measure of economic independence through the use of equitable devices - trusts and marriage settlements. ${ }^{20}$ Imported from England, along with the common law, these equitable techniques were adopted in some mid-Atlantic and Southern states. ${ }^{21}$ Massachusetts, without a fully developed and separate equity jurisdiction, provided a less hospitable environment for these methods. By the early nineteenth century, although some Massachusetts women and their families did apply to the common law courts for enforcement of marriage settlements or trusts, they were on uncertain terrain and success was by no means assured. ${ }^{22}$

208. Among other important provisions, the 1855 statute characterized as "sole and separate property" all property - real and personal - that a woman brought to the marriage or acquired after marriage by gift, inheritance, bequest, or devise. Thus, such property could not be reached by creditors to discharge any debts of the husband, whether arising before or after the marriage. 1855 Mass. Acts, ch. 304.

19. In recent years, there has been a dramatic increase in the study of the Married Women's Property Acts. For example, see N. BASCH, In THE EYes OF THE LAW: WOMEN, Marriage, and Property in Nineteenth-Century New York (1982); P. Rabkin, Fathers to Daughters: The Legal Foundations of Female Emancipation (1980); M. Salmon, Women and the Law of Property in Early america (1986); E. Warbasse, The Changing Legal Rights of MARried Women, 1800-1861 (1987); Chused, Married Women's Property Law: 1800-1850, 71 Geo. L.J. 1359 (1983). Historians have suggested various theories to explain the motivation for the passage of the Married Women's Property Acts. For a useful summary of these theories as well as fresh insights more generally about the Acts, see J. HOFF, LAw, GENDER, AND INJUSTICE: A LeGAL History OF U.S. WOMEN 119-35 (1991).

The language and images in the debate over married women's property not surprisingly may be found in other areas of law reform relating to issues of gender and the family. For example, see Clark, Matrimonial Bonds: Slavery and Divorce in Nineteenth-Century America, 8 LAw \& Hist. Rev. 25 (1990). See generally M. Grossberg, Governing the Hearth: Law and the Family in Nineteenth-Century america (1985).

20. See, e.g., M. SALMON, supra note 19, at 81-140.

21. For New York, see N. BASCH, supra note 19, at 72-88; for the South, see S. LEBSOCK, The Free Women of Petersburg: Status and Culture in a Southern Town, 1784-1860, at 54-86 (1984); Salmon, Women and Property in South Carolina: The Evidence from Marriage Settlements, 1730-1830, 39 WM. \& MARY Q. 655 (1982).

22. Marylynn Salmon summarized the legal situation as follows:

In Massachusetts, as in Connecticut, cases concerning trusts and marriage settlements were rare in the early reports.... Judges in Massachusetts felt unsure of their right to guarantee wives separate estates because ... the state had no inde- 
But Sarah Grimké, Simon Greenleaf, and Keziah Kendall were concerned not just with law. Each, witness to a world of evangelical religion and moral reform, understood that the debate over women's legal rights was cast as well in terms of moral discourse. And so each sought to justify his or her position by appealing to the highest moral authority, invoking the Bible, the gospels, and the meaning of Christianity. Sarah Grimké opened the debate.

\section{Sarah Grimké on the Legal Disabilities of Women}

"[A]ll the avails of her labor are absolutely in the power of her husband. All that she acquires by her industry is his. ..."23

Sarah Grimkés fifteen letters on the equality of men and women, published as Letters on the Equality of the Sexes and the Condition of Woman, ranged over a wide variety of topics - from the condition of women in Asia and Africa to the condition of women in Europe and America, from the intellect of women to the dress of women, from the legal disabilities of women to the ministry of women. As a Christian addressing other Christians, Grimké asserted her own reading of the golden rule, "I want my sex to claim nothing from their brethren but what their brethren may justly claim from them. ..."24

Long before Sarah Grimké wrote her Letters, she had "built a foundation" for her views, based on "her own (secret) studies of the law, and her knowledge of the Bible."25 She opened Letter I on "The Original Equality of Woman" with a declaration: "I shall depend solely on the Bible to designate the sphere of woman, because I believe almost every thing that has been written on this subject, has been the result of a misconception of the simple truths revealed in the Scriptures. ..."26 Her

pendent equity court. They believed that they could not, therefore, simply adopt the precedents of the English Chancery....

Partly as a result of this truncated equity jurisdiction, no legal tradition on trusts for married women developed in the colony and state....

Even after 1818, when common law courts gained jurisdiction over trust estates in Massachusetts, justices continued to interpret the related body of law conservatively.

M. SALMON, supra note 19, at 132-33, 137.

23. S. GRIMKÉ, supra note 11 , at 75 .

24. Id. at 102 . The golden rule is found in Matthew 7:12.

25. The Public Years, supra note 7 , at 13.

26. S. GRIMKE, supra note 11, at 31 . Sarah Grimké translated the Bible from original Greek and Hebrew sources, rejecting the King James translation, and provided her own original interpretations. Id. at 31-32, 38 . 
textual exegesis on the subject of original equality began with Genesis. Contradicting the traditional, patriarchal argument that the scriptures revealed the inequality of the sexes, Grimké insisted that a careful translation and interpretation of the original scriptures led to the opposite conclusion - women's equality to men. ${ }^{27}$ Even the very act of creation demonstrated, according to Grimké, that "there is not one particle of difference intimated as existing between [men and women]. They were both made in the image of God: dominion was given to both over every other creature, but not over each other."28 Furthermore, God's purpose in creating woman was to give man "a companion, in all respects his equal: one who was like himself $a$ free agent, gifted with intellect and endowed with immortality. ..."29

Developing her arguments for the equality of the sexes, Grimké described the deplorable social and legal conditions of women in Asia and Africa - "the treatment of women as wives is almost uniformly the same in all heathen countries"30 - as well as in Europe and America. Drawing examples from Lydia Maria Child's Brief History of the Condition of Women, in Various Ages and Nations, ${ }^{31}$ Grimke found that women everywhere were enslaved, treated as property, degraded, and "always in some way regarded ... as mere instruments of selfish gratification." ${ }^{32}$ How were women, by contrast, treated under American law? "The various laws [in the United States] ... leave women very little more liberty, or power, in some respects, than the slave." 33

Grimké's letter on the "Legal Disabilities of Women" began with the following observation:

There are few things which present greater obstacles to the improvement and elevation of woman to her appropriate sphere of usefulness and duty, than the laws which have been enacted to destroy her independence, and crush her individuality; laws which, although they are framed for her government, she has had no voice in establishing, and which rob her of some of her essential rights. ${ }^{34}$

Delving into the "mysteries of Blackstone," Grimké uncovered many

27. See Elizabeth Bartlett's discussion in S. GRIMKÉ, supra note 11, at 20-21. See also G. LERNER, supra note 7, at 192.

28. S. GRIMKÉ, supra note 11 , at 32 .

29. Id.

30. Id. at 49.

31. Child's Brief History was published in New York in 1835. For Grimke's reliance on Child see id. at 51; THE PUBLIC Years, supra note 7, at $204 \mathrm{n}$.

32. S. GRIMKÉ, supra note 11 , at 47.

33. Id. at 77 .

34. Id. at 71-72. 
of the inequities of the common law. ${ }^{35}$ While it was true, she acknowledged, that " " $[t]$ he husband is bound to provide his wife necessaries by law," "36 "[y]et a man may spend the property he has acquired by marriage at the ale-house, the gambling table, or in any other way that he pleases." ${ }^{37}$ Although a husband "adopted [his wife] and her circumstances together," "38 including the obligation to pay for her premarital debts, "[t]he wife's property [was] ... equally liable for her husband's debts contracted before marriage." 39

Grimké recounted several stories of women who had acquired property only to lose it to uncaring, profligate husbands. Yet she also strongly disapproved of the course taken by a woman who had "married without the least idea that she was surrendering her rights to all her personal property" and then attempted to conceal her wealth from her husband. ${ }^{40}$ Grimké cautioned:

The relation of husband and wife is too near and sacred to admit of secrecy about money matters, unless positive necessity demands it; and I can see no excuse for any woman entering into a marriage engagement with a design to keep her husband ignorant that she was possessed of property. If she was unwilling to give up her property to his disposal, she had infinitely better have remained single. ${ }^{41}$

“[A]buses do exist, and women suffer intensely from them, ..." Grimké concluded. "[E]very sentiment of . . religion and justice," urged Grimké, should lead "to repeal [of] these unjust and unequal laws, and restore to woman those rights which ... have [been] wrested from her." ${ }^{\prime 42}$ The problem was that some people, like Simon Greenleaf, thought that these laws were neither unjust nor unequal.

\section{Simon Greenleaf on the Legal Rights of Women}

"[Are] her rights ... not equal, though they may not always be identical, with our own." ${ }^{43}$

In June of 1840, The Christian Review, a Baptist quarterly printed

35. Id. at 73.

36. Id., quoting Blackstone.

37. S. GRIMKE, supra note 11 , at 73.

38. Id., quoting Blackstone.

39. S. GRIMKÉ, supra note 11 , at 73.

40. Id. at 75 .

41. Id.

42. Id. at 76.

43. Greenleaf, supra note 13, at 273. 
in Boston, published an article entitled "On the Legal Rights of Woman." 44 The writer was anonymous, as were all the Review's authors at this time ${ }^{45}$ The Review's authors also were primarily clergymen, ${ }^{46}$ but this essay was an exception because it was written by a lawyer-Simon Greenleaf ${ }^{47}$ Greenleaf was no stranger to the public topics of the day. As a participant in early nineteenth-century America's evangelical "benevolent empire," he joined his views on public affairs to his own religious beliefs. ${ }^{48}$ A devout New England low-church Episcopalian, Greenleaf was active in Bible, tract, temperance, missionary, peace, Sunday school, and colonization societies. ${ }^{49}$ So it was not unusual for him to have selected a religious periodical as a forum to express his views on the legal rights of women. The article also brought to conclusion his previous thoughts on the subject - he had delivered at least two lyceum lectures on the rights of women in the previous year or so. ${ }^{50}$

It was also not surprising that a religious journal would demonstrate interest in the subject. The established religious community had been thrown into an uproar by the appearance of the Grimké sisters in eastern Massachusetts in the summer of 1837 . Alarmed at the "dangers which at present seem to threaten the female character," the Congregational ministers of Massachusetts issued a Pastoral Letter in July of $1837 . .^{51}$

44. See Greenleaf, supra note 13.

45. F. MOTt, A History OF AMERICAN MAGAZINES, 1741-1850, at 666 (1957).

46. Id.

47. On authorship of the article, see supra note 13. See also Letter from Richard Fletcher to Simon Greenleaf (July 27, 1840) (commenting on Greenleaf's authorship of The Christian Review article) (Box 3, Folder 6, Simon Greenleaf Papers, Harvard Law School Library).

In all the modern treatments of the history of married women's property law, we have discovered only one mention of Greenleaf's article-Elizabeth Warbasse briefly discussed his anonymous essay in her exhaustive and exceptional 1960 doctoral dissertation. See E. WARBASSE, supra note 19, at 132-33. Since Greenleaf's papers had not yet been acquired by the Harvard Law Library, it would have been difficult for her at the time to ascertain that the author was Greenleaf.

48. See generally C. Foster, An ERrand of Mercy: The Evangelical United Front, 1790-1837 (1960); C. Griffin, Their Brothers' Keepers: Moral StewardSHIP IN THE UNITED STATES, 1800-1865 (1960).

49. For example, this pattern of participation ranged from his early membership in the Maine Peace Society (as a trustee in 1818) to his vice presidency of the American Bible Society at the time of his death in 1853. See Freeman, Samuel Freeman-His Life and Services, 5 [2d ser.] Collections \& Proc. Me. Hist. Soc'y 2, 28 (1894); H. Dwight, The Centennial History of the American Bible Society 543 (1916).

50. See supra note 5.

51. The PUblic YeARS, supra note 7, at 211. 
"The appropriate duties and influence of women," intoned the ministers, "are clearly stated in the New Testament. Those duties and that influence are unobtrusive and private..$^{52}$ Without mentioning the Grimkés by name, the ministers deplored the movement by women out of the private sphere and into the public domain: "We ... regret the mistaken conduct of those who encourage females to bear an obtrusive and ostentatious part in measures of reform, and countenance any of that sex who so far forget themselves as to itinerate in the character of public lecturers and teachers." ${ }^{3}$

Sarah Grimké certainly understood whom the ministers were attacking. She immediately responded with her third letter on the equality of the sexes. Comparing the ministers to Cotton Mather on the subject of witchcraft, ${ }^{54}$ Grimke drew her own conclusions about the appropriate spheres of women as expressed in the New Testament. Women, according to Grimké, were not to be relegated solely to a subordinate role in the private realm. "How monstrous, how anti-christian, is the doctrine that woman is to be dependent on man! Where, in all the sacred Scriptures, is this taught?"55

Simon Greenleaf, like the ministers, was concerned with the public impact of the Grimké sisters' tour, and there can be no doubt that he had them in mind as he wrote his essay. Even as he reiterated the disapproval of the clergy, Greenleaf used the public activities of women as an example of the legal equality of the sexes:

In whatever employment she may engage, the law affords her its protection. Should she choose to violate the proprieties of her station, whether by travelling in the character of public lecturer, by engaging with masculine energy in the distracting controversies of the day, or by any occupation which custom and propriety have assigned to the other sex, the law merely consigns her to the tribunal of public opinion, and condemns her only to its withering rebuke..$^{56}$

In fact, most of his essay was a direct response to ideas set forth by Sarah Grimké.

Greenleaf was not willing to concede Grimké anything-in religion or law. He, too, began his discussion with an analysis of the condition of women "in other nations, both in ancient and modern times." ${ }^{57}$ From

52. Id.

53. Id.

54. S. GRIMKÉ, supra note 11, at 37. See also G. LERNER, supra note 7, at 192.

55. S. GrimKÉ, supra note 11, at 39.

56. Greenleaf, supra note 13, at 277.

57. Id. at 270 . 
"savage tribes" where women were "always, and every where, [in] a state of abject slavery," to feudal lords, the Greeks, the Romans, the Chinese, he found women oppressed and treated as inferiors. ${ }^{58}$ Implicitly agreeing with Grimké's general descriptions, and using similar types of examples, Greenleaf nevertheless saw a very different lesson. By contrasting the harsh treatment of women in other cultures with the benevolent treatment of women under Christianity, he hoped that "[w]e shall better understand the value of her position in this country, ... and the depths from which she has been raised to her present most just elevation of rank in the Christian world." 59

Greenleaf's analysis of the legal rights of women started from an unstated premise - that Christianity was the basis of all true civilization. From this followed the proposition that in Christian culture, unlike other civilizations, women and men were treated equally. ${ }^{60}$ In addition, the law in Christian society guaranteed that men and women are treated equally. To establish this last point, Greenleaf structured his argument around three organizing concepts - the political, civil, and "connubial" or marital rights of women. ${ }^{61}$ "It is remarkable," Greenleaf asserted, "that the influence of Christianity, wherever it has been felt in any nation, has given woman a new station in society, releasing her from bondage, and rendering her at once the companion, the equal, and the friend of man. Hence Christianity has been scoffingly termed 'the religion of women." "62 Greenleaf was uncompromising on the subject of

58. Id. at $270,270-71$,

59. Id. at 270. Nancy Cott has observed,

Contrasts between the condition of women in New England and in the countries to which missionaries traveled made it plausible that the Christian gospel had "civilized" men's attitude to women. To appeal to a female charitable society for funds in 1829, the male trustees of the New Hampshire mission society asserted that "heathen" women were "ignorant-degraded-oppressed-enslaved. They are never treated by the other sex as companions and equals. ..." New Hampshire women by contrast were respected and free, and had access to knowledge.

N. Cott, The Bonds of Womanhood: "Woman's Sphere" in New England, 17801835 , at 131 (1977). Greenleaf alluded to the experience of missionaries in Asia. Greenleaf, supra note 13 , at 272 .

60. Greenleaf wrote: "It is therefore not to mere civilization,- - not to advancement in the arts of life, or to intellectual culture alone, that we are to look, for the elevation of woman to her proper rank in social existence. Another element must be sought, in the composition of society, to effect this result;-and that element has been found in the Christian religion." Greenleaf, supra note 13, at 272.

61. Greenleaf relied primarily on Massachusetts law to support his arguments, though he observed that the laws on these subjects were generally the same throughout the United States. Id. at 277 , n.

62. Id. at 272. "The 'feminization' of Protestantism in the early nineteenth century 
women's equality. "She is justly neither the servant, nor the sovereign of man; neither the slave of his will, nor the proper object of his obsequious servitude, or his adoration;-but his equal, his fellow-being, his partner in the social state." 63

But what of the political, civil, and marital rights of women? Women, just like men, were entitled to all the rights and protections offered by the Constitution, with only one exception: "that of electing and being elected to political office." ${ }^{64}$ Furthermore, women themselves had a "large and perhaps an equal share" in "originating" the "customs of society" that barred women from holding office. ${ }^{65}$ Thus, it was not so much the principles of government as the dictates of shared views of "propriety" that explained the prohibition. Greenleaf argued that

If she were eligible to one political office, it would be because her sex does not unfit her for any; and the same code that would admit female legislators, ought, in equal reason, to make them eligible to all other offices. But how would ladies themselves regard a female sheriff, or captain of militia? The very constitution of society has, of necessity, allotted these employments to man. Not that he is wiser, and thus more capable of exercising them; but because, in the distribution of social duties, these are more befitting his sex....66

The right to vote was similarly denied to all women. Greenleaf echoed both the founding fathers' concern that republican society might be divided by faction and the patriarchal fear that the cult of domesticity might be breached.

Amid the storms which beat without, in the political world, the domestic hearth is yet the sanctuary of repose, and the domestic altar still receives the offering of united hearts, to the God of peace and love. But if, in addition to all our other sources of party strife, as if the thousand existing elements of contention could not suffice, we were to array male and female electors with their candidates in opposition, it is easier to imagine the uproar that would ensue, than to foretell when or how it would end. ${ }^{67}$

Female suffrage was equated with social discord. "The experience of all

was conspicuous." N. CoTT, supra note 59, at 132. For discussion of the "feminization" of religion, see generally id. at 126-48; A. Douglas, THE FEMINIZATION OF AMERICAN CUlture (1977); Welter, The Feminization of American Religion, 1800-1860, in CLIO'S Consciousness Raised: New Perspectives on the History of Women 137 (M. Hartman \& L. Banner eds. 1974).

63. Greenleaf, supra note 13, at 272.

64. Id. at 274.

65. Id.

66. Id.

67. Id. at 274-75. 
nations," Greenleaf observed, "has shown that the state of society has been rendered miserable whenever both sexes have mingled in party politics." ${ }^{8}$ And, he concluded, "It is for the preservation of social peace, therefore, and of domestic happiness, that our law has assigned the labor of moving the political machine to men. In this division of labor, the rights of woman are not infringed."69

With regard to the civil rights of women "when of age and unmarried," Greenleaf emphasized that it was not law which constrained women, but the "usages, and customs of society." "She was free to hold any job (including "preacher or public lecturer"), and even own stock, and vote as a shareholder, "[f]or these are private enterprises, having nothing to do with political government."" An unmarried woman could sue or be sued, be an executor or guardian. And, because the colonies had early rejected primogeniture, a woman "inherit[ed], equally with her brothers, the paternal estate." 72 Thus, women faced "no restrictions but those which decency," not the law, "impose[d]."

A thread running through the essay was the significance of woman's separate sphere - the unwritten boundaries between men's and women's roles. Although he did not put woman on a pedestal, nor view her as man's inferior in intellect or will, Greenleaf's sense of Christian duty shaped his desire to protect her: "From the cradle to the grave, the law watches over her with untiring vigilance, and guards her rights with paternal care." ${ }^{74}$ Moreover, Greenleaf deftly set the public realm apart from the private in distinguishing between the political rights of all women and the civil rights of unmarried women. "[S]ubject to those restrictions in political matters, which ... public expediency and even public necessity have created," he was "not aware of any distinction between the legal rights of unmarried women, and of men."75

68. Id. at 275.

69. Id.

70. Id. at 276.

71. Id.

72. Id. at 277.

73. Id. at 276.

74. Id. at 277. See also id. at 272 (rejecting the chivalric tradition); id. at 273 (admitting the intellectual equality of men and women). Though Greenleaf generally emphasized the paternalistic qualities of the common law, others found paternalism more often demonstrated by courts of equity. "[W]e cannot fail to observe the parental solicitude [on the subject of married women], with which Courts of Equity administer to the wants, and guard the interests, and succor the weakness of those, who are left without any other protectors, in a manner, which the Common Law was too rigid to consider, or too indifferent to provide for." 2 J. STORY, COMMENTARIES ON EQUITY JURISPRUDENCE 655 (1836).

75. Greenleaf, supra note 13, at 277. 
The rights of married women, however, were more difficult to explain. Nevertheless, as Greenleaf ranged over a variety of legal rules that affected the marital relationship ${ }^{76}$ he emphasized the sacred and felicitous nature of the marriage bond. He described marriage as "a partnership, on terms of equality; - an embarkation in the same vessel, for the voyage of life; - a community of interests, - a union of wills and minds; - a surrender... a mutual pledge." " He argued that only "[i]n a limited and qualified sense" did the wife's "very legal existence" become "merged" with her husband's. ${ }^{78}$ The notion of marital unity, for Greenleaf, was "not a principle of the law; but a figure, employed to illustrate a principle, adopted for her protection." "

According to Greenleaf, nowhere was this "protection" more appropriate and necessary than in the laws concerning the property rights of married women. Although the husband had a right to "absolute" ownership of "the wife's money and goods, in her actual possession at the time of the marriage," 80 Greenleaf dismissed this as a mere technicality. Because the wife's property, in practice, became part of "a common fund, to which both may resort, for all the ordinary purposes of support and reasonable enjoyment, it can make but little difference, in the results, by whose name it is called." ${ }^{11}$ While it was true that the husband received the "profits" from all the real property his wife brought to the marriage, "her lands and buildings [were] still her own" because she retained her "inheritance." ${ }^{\prime 2}$ In addition, Greenleaf maintained, "After what has been said, of the reasons for giving the husband the control of the wife's property, it is almost superfluous to observe, that he is entitled to the fruits of her labor."83

On the other hand, marriage could impose significant obligations on a man, since "by the marriage the husband [was] made instantly liable for all the debts owed by the wife. The rule has no regard to her pioperty, whether it be much, or little. If she brought him but five hundred, and owed ten thousand dollars, he is liable to pay it all."84 Sarah Grimké

76. For instance, Greenleaf's discussion, at some point, touched on the subjects of criminal law, family law, torts, contracts, evidence, decedent's estates, as well as property. See id. at 278-89.

77. Id. at 278 .

78. Id. at 279.

79. Id.

80. Id. at 281 .

81. Id.

82. Id.

83. Id. at 282 .

84. Id. at 279. 
did not consider this rule particularly onerous to men since all the interests he acquired in his wife's property by marriage could be used to discharge his own premarital debts. ${ }^{85}$ Yet, as Greenleaf noted, if the wife desired "any better provision, or any other rights, or greater liberty, than the rules of law have prescribed for her," she could enter into an agreement with her "intended husband" maintaining her rights over her separate estate. ${ }^{86}$

All of these rules led Greenleaf to an unmistakable conclusion: married women, possessed of legal rights and privileges, were protected by the common law. Their rights were evidence of their equal treatment with men. He contended,

When, therefore, complaint is made of the hardship of the law, in transferring to the husband, upon the marriage, all the wife's personal property, the fruits of her industry and the income of her lands; let it be remembered that by the same act he is made responsible for all the debts she may owe; is liable for her decent and respectable maintenance; is answerable, to the extent of all his property, for her language and her behaviour, though she brought him not a dollar, and though he has married a spendthrift or a shrew; and that her claims on his estate are beyond his force to resist, his art to elude, or his power to control. ${ }^{87}$

Sounding a final defensive note, Greenleaf admonished, "Restless spirits, may raise discontents with the system; for it is always easier to point out faults, than to correct them." ${ }^{88}$ For Keziah Kendall, however, it had been far more difficult to live with the faults of the system, than to point them out. Greenleaf's lecture, though, awakened her "restless spirit."

\section{Keziah Kendall on the Legal Wrongs of Women}

"What I have suffered, I cannot tell you." ${ }^{9}$

Little is known about Keziah Kendall other than what she revealed in her letter to Simon Greenleaf. ${ }^{90}$ She was thirty-two at the time she

85. See supra note 39 and accompanying text.

86. Greenleaf, supra note 13 , at $285,284$.

87. Id. at 286.

88. Id. at 289.

89. Kendall Letter, supra note 2.

90. No letter or draft of a letter from Greenleaf to Kendall has been found in the Greenleaf papers at the Harvard Law School Library, if indeed he responded to her. Because her letter to Greenleaf contained no identifying address or location (or date 
wrote the letter and lived with her two sisters on a dairy farm near Cambridge. The three sisters had been named after the three daughters of Job-Jemima, Keziah, and Keranhappuck. ${ }^{91}$ The Kendall sisters

for that matter), it would have been difficult, if not impossible, for him to answer her letter. She may also have been using a pseudonym. It could be that the absence of a return address indicated Kendall's belief that no response was necessary or desired. Several of our colleagues have also suggested that the letter may have been a fictional account written by a contemporary feminist.

Jerome E. Anderson, reference librarian at the New England Historic Genealogical Society, "found no trace" of Keziah Kendall or her sisters "in the records of Massachusetts." Anderson reported that

[t]he Kendalls are a numerous family in Massachusetts, but one not well treated in printed genealogies. Since the sisters did not appear in such printed form I then checked the vital records of Massachusetts. ... None of the three women appeared in records of birth, baptism or marriage....

State-wide registration of vital records began in Massachusetts in 1841. Examination of the marriage and death records indexes for the period 1841-1895 showed no record for any of the women. Only very long celibate lives could explain their absence from the record.

A check of the indexes to probate records for a number of counties in eastern Massachusetts showed no entries for the women under Guardianship, administration, probate, etc.: Essex (-1840), Middlesex (-1909), Norfolk (-1900), Suffolk $(-1910)$, and Worcester $(-1897)$.

Finally, the indexes to the Federal Censuses of Massachusetts revealed no household headed by any of the three sisters.

Letter from Jerome E. Anderson to Alfred S. Konefsky (August 26, 1991). It is also possible that the Kendall sisters moved out of the state, which might explain the difficulty in locating them in certain types of Massachusetts records.

In addition, we examined all the standard bibliographical sources on women's history, searching for Keziah Kendall in letters, diaries, journals, manuscript collections, etc. The collections at Smith College, the Schlesinger Library at Radcliffe College, Harvard University, the Massachusetts Historical Society, and Old Sturbridge Village were also consulted. Keziah Kendall seems to have been one of those women who quietly led her life, leaving no traces behind, other than her letter to Greenleaf. The letter provides us with another example of an obscure, though articulate and intelligent, woman hidden from view, and therefore not "notable."

91. Job 42:14. These names "were not favored by earlier generations of Kendalls.... [T] The names of Job's daughters, never frequently given, are found most often in the eighteenth century." Letter from Jerome Anderson, supra note 90.

During the eighteenth and nineteenth centuries a number of Kendall families settled in a southwest to northeast arc in Middlesex and Worcester counties. In particular, many Kendalls clustered in the town of Woburn and tended to branch outward from there. See generally O. Kendall, Memorial of Josiah Kendall, One of the First SetTlers of Sterling, Mass., and of SOME of His ANCEStors, and of His DESCENDANTS (1884). Laura Pangallozzi uncovered for us records of several Keziah Kendalls in eighteenth-century Middlesex towns. See, for example, VITAL RECORDS OF SHERborn, MASSACHUSETTS, TO THE YeAR 1850, at 52 (T. Baldwin comp. 1911); Wo- 
owned and managed their farm; their parents and only brother were dead. ${ }^{92}$ The sisters had "a good estate - comfortable house - nice barn, garden, orchard \&c and money in the bank besides." Jemima, the eldest, was "a very good manager in the house, keeps everything comfortablesees that the milk is nicely prepared for market-looks after everything herself, and rises before day, winter and summer. ..." Because Jemima "never had any head for figures," Keziah was "expect[ed] . . . to keep all accounts, and attend to all business concerns." Keranhappuck, called Kerry, was "only nineteen, and as she was a little girl when mother died, " Keziah wrote, "we've always petted her, and let her do as she pleased, and now she's courted. Under these circumstances the whole responsibility of our property, not less than twenty five thousand dollars rests upon me."93

In mid-nineteenth-century Massachusetts, the Kendall sisters were unique in many respects. Male ownership of lands-particularly farmswas the prevailing pattern in the new republic, and it was extremely rare for single women to own and run farms. ${ }^{94}$ A statistical survey of the Northeast, based on the 1860 Census, revealed that only about four percent of farm households were headed by females. ${ }^{95}$ The economic

BURn Records of Births, Deaths, and Marriages from 1640 to 1873: Part I, Births 139 (E. Johnson comp. 1890): id., PART III, Marriages, at 153 (E. Johnson comp. 1891).

92. Though we do not know how the Kendall sisters acquired their property, it is most likely that they inherited their interests through either their father's or mother's estate. If the surviving parent died intestate, the three daughters and son would have inherited the farm equally. "By 1800 in most states, sons and daughters received equal shares in real and personal property; there was no longer any meaningful distinction for purposes of children's inheritances." C. Shammas, M. Salmon \& M. Dahlin, INHeritanCe in America from COlonial Times to the Present 67 (1987).

93. Kendall Letter, supra note 2.

94. J. Jensen, With These Hands: Women Working on the LANd 33 (1981); see also C. SaChs, The Invisible Farmers: Women in Agricultural Production 12 (1983). Although sons and daughters inherited property in equal shares, fathers nearly always willed farm lands to their sons, not their daughters. Sachs notes that "women had relatively minimal access to land.... Fathers controlled the land, determining its use and how it was to be distributed to their sons.... Daughters could not expect to inherit land except in the absence of sons." Id. Nancy Grey Osterud has described similar patterns of inheritance and transmission of land in the Nanticoke Valley in New York during the late nineteenth century. N. OSTERUD, BONDS OF COMMUNITY: THE Lives of Farm Women in Nineteenth-Century New YoRk 62-67 (1991). See also J. JENSEN, LOOSENING THE BoNDS: Mid-ATLANTIC FARM WOMEN, 1750-1850, at 2122 (1986), for a discussion of women's roles in this pattern of wealth transmission and conservation in mid-eighteenth-century Pennsylvania farm country.

95. J. Atack \& F. Bateman, To Their OWN Soll: Agriculture in the ANTEBel- 
independence of the Kendall sisters also set them apart from women of their age group. ${ }^{96}$ Most women married, ${ }^{97}$ and those who did not had limited choices of employment. The many single women who left their family farms in New England to work in textile mills attained a certain degree of autonomy, but their financial independence may have been constrained - some "mill girls" sent money home to their fathers and brothers. ${ }^{98}$ When they remained at home in male-headed households, women contributed their labor to the farm economy, with little or no control over its assets. ${ }^{99}$ Thus, Keziah Kendall's responsibility for managing the "business" of a farm and assets worth twenty-five thousand dollars was exceptional for a woman of her day. This estate represented substantial wealth in the rural economy of Massachusetts. ${ }^{100}$

LUM NORTH 26-27 (1987). In the Northeast sample of counties surveyed, the New England states of Maine, Massachusetts, and Rhode Island were excluded. Id. at 22.

96. On economic independence for single women, see L. CHAMBERS-SCHILLER, LIBERTY, A Better Husband-Single Women in America: The Generations of 1780-1840, at 67-82 (1984). For a discussion of the relationship of single rural women to family and community in late nineteenth-century New York, see N. OSTERUD, supra note 94, at $123-30$.

97. Nancy Cott has observed that "more than 90 percent of American women married" and, according to her best estimate, "New England women married at an average age of 22 or 23 during this [1780-1835] period." N. CotT, supra note 59, at 14, 13.

98. Id. at 55-56. Thomas Dublin disputes Cott's assumption about the frequency with which female mill operatives in Lowell sent money home. See T. DUBLIN, WOMEN at Work: The Transformation of Work and COMmunity in Lowell, MassaCHUSETTS, 1826-1860, at 38-40, 261 n.33 (1979).

99. Jack Larkin has written that “[m]en's and women's tasks on American farms were intertwined and almost totally interdependent. But in space, time, tools and authority they were distinct. ... American families worked as patriarchal units, governed by their male heads. Men's work, and men's decisions about work, were primary." J. LARKIN, The ReshapING OF EVERYDAY LIFE, 1790-1840, at 17 (1988). This point is amplified by Elizabeth Fox-Genovese:

As a rule, ... with the notable exception of black slave women, women's participation in agriculture followed a combination of time-honored European and American attitudes towards gender roles. ... The traditional cleavage between men's and women's customary roles followed the distinction between the house and the fields, with some blurring in the case of dairies, gardens, and orchards. ... Originally, many such distinctions derived from the assumption that men dealt with the outside world, notably with markets, while women dealt with basic needs of the household.

Fox-Genovese, Women in Agriculture during the Nineteenth Century, in AGRICULTURE and National Development: Views on the Nineteenth Century 267, 270 (L. Ferleger ed. 1990).

100. Twenty-five thousand dollars seems like a great deal of money for a farmer at this time. Statistics about wealth in this period are very difficult to find and analyze. Various types of data, like probate records, tax lists, and census figures, yield results 
Their wealth may have been due to the fact that the Kendall sisters almost certainly owned a dairy farm. Keziah described her own management of the farm "accounts and business concerns," the care with which her sister prepared milk "for market," and the fact that they owned cattle and a "nice barn." Milking and butter-making had traditionally been "perceived as women and children's work" which was only of marginal commercial value to most farms. ${ }^{101}$ But, within the

that are difficult to compare. Using tax-assessment lists, Edward Pessen has estimated that fourteen percent of the population of Boston in 1833 possessed wealth in excess of five thousand dollars (with only four percent owning wealth above thirty thousand dollars) and that nineteen percent of the population of Boston in 1848 possessed wealth in excess of four thousand dollars (with only four percent owning wealth above thirtyfive thousand dollars). E. Pessen, Richés, Class, and Power Before the Civil War 39 (1973). The Kendall sisters' wealth also seems substantial in comparison to rural wealth in western Massachusetts. See C. ClaRK, The Roots of Rural Capitalism: WESTERN MASSACHUSETTS, 1780-1860, at 263-67, 293, 303 (1990). In Shrewsbury, Worcester County, "an 1830 valuation of $\$ 14,825$," probably from tax records, placed Thomas Ward, Sr., as the second wealthiest man in town, with "more than double the person who ranked third." Baker \& Paterson, Farmers' Adaptations to Markets in EarlyNineteenth-Century Massachusetts, in The Farm: The Dublin SEMINAR FOR New ENGland FolkLife, ANNual Proceedings, June 14 AND 15, 1986, at 105 (P. Benes \& J. Benes eds. 1988).

Clarence Danhof reports "an account of a [Massachusetts] farm comprising eightyfive run-down acres, purchased in 1843 for $\$ 4,337$." The farm's location in Massachusetts

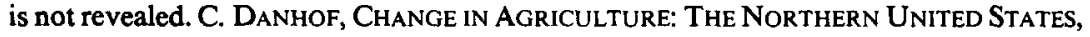
1820-1870, at 112 (1969). "The arithmetic mean of real estate holdings was $\$ 1,001$ for the 5.0 million free men in 1850." L. SOLTOW, MEN AND WEALTH IN THE UNITED STATES, 1850-1870, at 63 (1975). For information derived from the 1850 census for Massachusetts on the "[a]verage value of farmland and buildings per acre," see FARM Real Estate Values in the United States by Counties, 1850-1959, at 23 (T. Pressly $\&$ W. Scofield eds. 1965). In 1850, the average value of a farm (including land and buildings) in the United States was estimated at $\$ 2,258$. Id. at 6 . Of course, without knowing the location and size of the Kendall farm, it is impossible to make any certain claims about its comparative value. Keziah Kendall's own estimate of her family's wealth no doubt included more than the value of their real property.

By contrast, Simon Greenleaf's estate at his death consisted of personal property valued at approximately thirty-one thousand dollars, real property valued at approximately ten thousand dollars, as well as copyrights valued in excess of fifteen thousand dollars. Schedule of the Estate of Simon Greenleaf, Middlesex County Probate Court, Cambridge, Massachusetts (1853).

101. J. ATACK \& F. BATEMAN, supra note 95, at 152-53. Atack and Bateman have concluded that "few truly commercial specialized dairy farms existed before the Civil War. Dairying was a secondary economic activity for most farmers, but a primary one for only a few." Id. at 161 . Joan Jensen, however, has stressed that "[r]egardless of the ongoing debate over how much power women had, their contribution to economic development was clear. ... Contemporary historians' designation of dairying as a secondary contributor to the farm economy because it was 'women's work' perpetuates 
generally uncertain farm economy of the late 1830 s, dairy farms were expanding into local, urban markets. The Kendall family farm would have been well positioned to take full advantage of the Boston market for dairy products. Butter, which could be preserved without refrigeration for long periods and transported substantial distances, entered the growing urban markets of New England and the Mid-Atlantic. ${ }^{102}$ The development of a commercial market for butter increased the number of dairy farms as well as the significance of dairy farming in both men's and women's lives. ${ }^{103}$

Before the development of adequate methods of refrigeration, the producers of fresh milk did not have to worry about competition from outside a limited geographic area. ${ }^{104}$ While the rapid expansion of rail transportation helped milk farmers within local markets, it subjected all other farm products to competition from distant producers. ${ }^{105}$ "As cities and manufacturing towns swelled in population, they called for more and more fresh milk. Farmers in town or within hauling distance turned from general farming to milk production. ..."106 Because of these market factors that favored the production of fluid milk, as well as the

nineteenth-century men's own devaluation of women's contribution to the development of butter making." J. JeNSEN, PROMISE to THE LAND: ESSAYS ON RURAL WOMEN 183, 185 (1991). The author of an econometric analysis of work on antebellum farms has concluded that "adult females were quite important in northeastern diary farming." Craig, The Value of Household Labor in Antebellum Northern Agriculture, 51 J. ECON. Hist. 67, 80 (1991). For an interesting analysis of the roles of women and men in English dairying, see Valenze, The Art of Women and the Business of Men: Women's Work and the Dairy Industry c. 1740-1840, 130 PAST \& PRESENT 142 (1991).

102. See J. JENSEN, supra note 94 , at 108-12, for a discussion of the methods used in the early nineteenth century to preserve butter and prepare it for markets in Pennsylvania.

103. See generally id. at 113. For a discussion of "The Economics of the Butter Trade," see id. at 79-91. The commercial importance of milk and butter production also affected the ways in which farm households divided labor along gender lines. In her study of late nineteenth-century farms in south central New York, historian Nancy Osterud found that "[t]he allocation of tasks between women and men was most flexible in the dairy process, perhaps because dairying was conducted in a domain between the fields and the house and involved a myriad of time constraints." N. OSTERUD, supra note 94 , at 150 .

104. See, e.g., Baker \& Paterson, supra note 100, at 106. Atack and Bateman note that "[d]airies from 10 to 30 miles distant from Boston were shipping some fluid milk to that city by rail in the early 1840 s. Yet, the Boston milkshed never extended beyond 65 miles before $1870 . .$. " J. ATACK \& F. BATEMAN, supra note 95, at 149.

105. J. SChlebecker, Whereby We Thrive: A History of American Farming, 1607-1972, at 94-95 (1975).

106. H. Russell, a long Deep Furrow: Three Centuries of Farming in New ENGLAND 355-56 (1976). 
arduous and time-consuming labor involved in butter-making, it is very likely that the Kendall sisters primarily produced fresh milk and sold it through a middleman. Within the Boston milkshed of the time, "[o]ften nearby dairies delivered the milk directly to consumers, but many farmers sold to milk dealers, whose cans the farmer filled and cooled in a well or with ice for delivery the following day."107

Indeed, it was the Kendall's "milkman" who "brought word when he came from market" that Simon Greenleaf was going to lecture on the legal rights of women. ${ }^{108}$ It would not have been unusual for Keziah Kendall to have attended a lyceum lecture. "At the very beginning" of the lyceum movement in New England in the 1820s and 1830s, the lectures were "designed for artisans and farmers," instructing them in "the practical application of science-which would result in better workmen and more efficient farmers. . .." ${ }^{109}$ Even as the lyceum movement, around 1840, outgrew its original attention to practical education and began to focus on lectures of broader cultural significance, it managed to retain its audience. ${ }^{110}$ Keziah Kendall's interest had been piquedshe thought she would go to hear Simon Greenleaf and "learn."

It is clear from Kendall's letter that the lecture she heard was an early version of Greenleaf's published article. Many of the phrases and arguments that she referred to appeared in his essay. ${ }^{1 "}$ " Kendall wrote, "We all know about a widow's thirds, ${ }^{12}$ and we all know that a man must maintain his wife, and we all know that he must pay her debts, if she has any. ..." "[B]ut," she observed sardonically, "I never heard of a yankee woman marrying in debt."113

107. Id. at 356.

108. Kendall Letter, supra note 2.

109. C. Bode, The American Lyceum: Town Meeting of the Mind 30 (1956).

110. Id. at 250.

111. While it is possible that Greenleaf had Kendall's letter in mind as he prepared his article on women's rights for publication, there is no concrete evidence that he was responding directly to any of her views.

112. Kendall is referring here to Greenleaf's discussion of dower rights. See Greenleaf, supra note 13 , at $285-86$.

113. Kendall Letter, supra note 2. Suzanne Lebsock noticed, "[t]he most striking feature of the real estate bargains struck by Petersburg's women was the near absence of speculation.... With credit, too, the women's approach tended to be conservative. The debts recorded in the deed books were secured debts. .. From all appearances, the women of Petersburg did their best to avoid indebtedness altogether." S. LEBSOCK, supra note 21 , at 126,127 . This confirmation of Kendall's insight by evidence from Virginia might lead one to conclude that the critical difference was not geographic region, but gender. Lebsock offers some evidence that women and men thought differently about property. Id. at 112-45. 
As she systematically rejected Greenleaf's arguments, Kendall insisted from the start that there was no basis to his claim of the legal equality of the sexes. "You mention that women here, are not treated like heathen and Indian women - we know that - nor do I think we are treated as Christian women ought to be, according to the Bible rule of doing to others as you would others should do unto you." 114 This was a particularly stinging rebuke to Greenleaf, since his argument assumed that Christianity had elevated women from their degraded status in nonChristian societies to a position of equality with men. ${ }^{115}$ Sarah Grimké, similarly, had asked only for the application of the "golden rule" as a principle of true equality. "I am told (not by you)," Kendall continued, "that if a woman dies a week after she is married that her husband takes all her personal property and the use of her real estate as long as he lives - if a man dies his wife can have her thirds-this does not come up to the Gospel rule."116

Nor did Kendall agree with Greenleaf's analysis of the political rights of women. As an independent landowner subject to taxation, she was particularly angered because she could not vote. "Now we are taxed every year to the full amount of every dollar we possess - town, county, state taxes - taxes for land, for movables, for money and all." At another lyceum lecture that she attended, Kendall had heard "that the Americans went to war with the British, because they were taxed without being represented in Parliament." She saw no distinction between the plight of revolutionary Americans and herself. "I have no voice," she complained, "about public improvements, and I dont see the justice of being taxed any more than the "revolutionary heroes' did." 117

Sarah Grimké also had linked the political rights of the "daughters of New England" to the causes of the American revolution - taxation without representation was "a similar injustice" for all American women to bear. ${ }^{118}$ Grimke, however, at least at this time in her life, was not in favor of women's suffrage: "I had rather we should suffer any injustice or oppression, than that my sex should have any voice in the political

114. Kendall Letter, supra note 2.

115. See supra note 60 and accompanying text.

116. Kendall Letter, supra note 2.

117. Id. For an historical and wonderfully polemical overview of the problem in Massachusetts, see W. Bowditch, TAXation of WoMEN IN MASSACHUSETTS (1875). And, for a post-Civil War account of a dispute over taxation without representation involving women farm owners in Connecticut, see J. SMIth, ABby SMITH AND Her Cows (1877).

118. S. GRIMKÉ, supra note 11 , at 76. 
affairs of the nation." 119 Keziah Kendall, though, wanted to vote. Public office holding was another matter. "I dont want to go representative or anything else," she wrote, "any more than I do to be a "constable or a sheriff'..."120 (offices dismissed by Greenleaf as inappropriate for women), but voting, and therefore actual representation, was critical.

Kendall, however, reserved her deepest insights about the system of women's rights for her stories about her own life. The immediate event that renewed Kendall's concern about women's property rights was the impending marriage of her younger sister, Kerry. "The young fellow that is engaged to our Kerry, is a pleasant clever fellow, but he is not quite one and twenty, and I dont s'pose he ever earned a coat in his life." The prospect of this "pleasant" but inexperienced young man as the absolute owner of Kerry's one-third share of the Kendalls' bank accounts and dairy cows, entitled to a third share of the farm profits, was unsettling to Keziah. "I am not over fond of money," she wrote, "but I have worked hard ever since I was a little girl, and tried to do all in my power to help earn, and help save, and it would be strange if I did not think more of it than those who never earned anything. . .."121

Greenleaf suggested that a woman who wanted "the control of her own property" after marriage could accomplish this "[i]f ... she stipulated with her intended husband. ... articles of agreement, executed before marriage... . [which] the law obliges the husband faithfully to perform." ${ }^{22}$ In fact, Keziah Kendall had proposed a similar solution to Kerry, "but she, poor girl has romantic notions owing to reading too many novels." Kerry "would not hear of such a thing - 'What take the law to keep my property away from James before I marry him - if it was a million of dollars he should have it all." "[T]he law," Kendall chided Greenleaf, "is in fault here - to tell you the truth I do not think young men are near so careful about getting in debt as girls, and I have known more than one that used their wife's money to pay off old scores." 123

119. Id. See Elizabeth Bartlett's discussion of Sarah Grimké's acceptance of women's fundamental right to vote after the Civil War, id. at 126-27, as demonstrated by Grimke's unpublished manuscript, "Condition of Women," id. at 127-33. Bartlett noted, "[T]he main point of this essay ["Condition of Women"], that women be granted full political rights and opportunities, contradicts Grimké's earlier sentiments, expressed in the Letters, that women should avoid the political arena altogether. This is a significant change in her thought." Id. at 127. See also G. LERNER, supra note 7, at 334.

120. Kendall Letter, supra note 2.

121. Id.

122. Greenleaf, supra note 13 , at $284,285$.

123. Kendall Letter, supra note 2. 
The relationship between a young man's risk taking and his inability "to pay off old scores" was a painful subject for Keziah Kendall. She knew that even if a prospective husband had no intention of using his wife's money to discharge his premarital debts, creditors would not be so scrupulous. Throughout his discussion of married women's property rights, Greenleaf never mentioned that a husband's premarital creditors could reach all the interests that a husband acquired in his bride's property. While Sarah Grimké understood the consequences of this rule when it was linked to a wife's total lack of control over her economic wealth, ${ }^{124}$ Keziah Kendall had lived with the hard choices the law demanded.

"[W]hen I was young," she told Greenleaf, "I had a lover, Jos. Thompson. ..." Joseph had gone "into business in a neighboring town." Within "a year or two," wrote Keziah, "Joe failed, he met with misfortunes that he did not expect, - he could have concealed it from me and married, but he did not-he was honorable, and so we delayed." His creditors "were stiff and held out, and thought by and by we would marry, and they should get my property." Joe "lost his spirits," found it difficult to start up a business again, and "thought he must go to sea. I begged him not to," Keziah revealed, "and told him we should be able to manage things in time, but he said no-he must try his luck, and at least get enough to settle off old scores and then he would come here and live and we would make the best of what I had." Joseph never returned. "We parted-but it pleased God he should be lost at sea. What I have suffered I cannot tell you."12s

The lesson of this. story was clear to Keziah Kendall. The law was wrong, she lectured Greenleaf.

[I]f it had been a thing known that I should always have a right to keep possession of my own, he need never have gone to sea, and we might have lived happily together, and in time with industry and economy, he might have paid off all. I am one that cant be convinced without better reasons than I have heard of, that women are dealt with by the "gospel rule." There is more might than right in such laws as far as I can seeif you see differently, do tell us next time you lecture. ${ }^{126}$

A rule designed to preserve a particular view of social order and hierarchy had instead, in Kendall's estimation, ironically contributed to social dislocation.

"To be sure," Kendall observed, "I do not wish to go about lecturing

124. S. GRIMKÉ, supra note 11 , at $73,75$.

125. Kendall Letter, supra note 2.

126. Id. 
like the Misses Grimkie [sic]." But she did remind Greenleaf of one of the Grimkés' themes: "[W]omen are kept for slaves as well as menit is a common cause, deny the justice of it, who can!" "Now," she appealed to him, "I have taken this opportunity to ask you to give us a remedy for the 'legal wrongs' of women.... The fathers of the land should look to these things - who knows but your daughter may be placed in the sad situation I am in, or the dangerous one Kerry is in." 127

\section{The Daughters of Job}

At the conclusion of the Old Testament Book of Job, after having tested Job's faith and integrity, God not only "restored [his] fortunes," but gave him "twice as much as he had before." 128 The Lord "blessed the latter days of Job more than his beginning": $:^{129}$ in addition to granting him great wealth, he also favored him with a new family - "seven sons and three daughters." 130 The names of Job 's daughters were Jemimah, Keziah, and Kerenhappuch, and "in all the land there were no women so fair. ..." ${ }^{31}$ Faced with new wealth and a new family, Job confronted the question of how to provide for the distribution of his fortune to his children. His solution, extraordinary under ancient law, symbolized Job's basic sense of equity and fairness, for he gave his three daughters "inheritance among their brothers." 132

Hebrew law gave "women no inheritance rights except in the case where there [were] no sons." ${ }^{133}$ In the Bible, the daughters of Zelophehad approached Moses among others, lamenting that their "father had died in the wilderness" and had "left no sons." The daughters pleaded, "Let not our father's name be lost to his clan just because he had no son!"134

127. Id.

128. Job $42: 10$.

129. Job $42: 12$.

130. Job $42: 13$.

131. Job 42:14-15. One biblical commentator noted that "the beauty of his daughters is mentioned as a public indication of special blessing... The names of Job's three daughters probably represent beauty and beautification. Jemimah means 'turtle dove' The dove was a symbol of beauty and love.... Keziah means 'cassia', an aromatic plant used in perfumes. ... Keren-happuch seems to mean 'horn of antimony' a black powder used for beautifying the eyes. ..." N. HABEL, THE BooK OF JOB: A COMMENTARY 585 (1985).

132. Job 42:15.

133. J. Milgrom, Numbers: The Traditional Hebrew Text with the New JPS Translation COMMENTARY 482 (1990).

134. Numbers 27:1-4. 
Moses agreed to bring "their case before the Lord. And the Lord said to Moses, 'The daughters of Zelophehad are right." "135 God then issued a series of laws governing patterns of inheritance in the absence of male descendants. The first rule stipulated that "[i]f a man dies, and has no son, then you shall cause his inheritance to pass to his daughter."'136 Only in the absence of sons, then, could daughters inherit. Therefore, "[b]y giving his daughters an inheritance with their brothers[,] Job ... continued a policy of justice and equality in his life which went beyond the normal practice of the ancient world."137

The three Kendall sisters, named after the daughters of Job, carried a special legacy. Keziah Kendall, in particular, embraced and then extended the ethic implicit in the biblical account of Job's treatment of his daughters. Massachusetts women, by this time of course, could inherit equally with their brothers when parents died intestate. ${ }^{138} \mathrm{Ag}$ ricultural lands, however, still passed primarily to sons under their parents' wills. ${ }^{139}$ Very likely Keziah had become an independent landowner, sharing the farm with her sisters, because their only brother did not survive. She believed from personal experience that the legal status

135. Numbers 27:6-7.

136. Numbers 27:8. "The right of daughters to inherit falls outside the general scheme; it needed a special divine judgment to validate it. ..." M. NOTH, NUMBERS: A COMMENTARY 212 (1968). The rules were ultimately derived from the requirements of primogeniture established in Deuteronomy 21:15-17. According to a biblical commentator, "The Bible, in its earliest stages, presumes a tightly knit clan structure; the foremost goal of its legal system was the preservation of the clan. Biblical law thus rests upon a strict patrilineal-agnatic principle of inheritance that prevents transfer of land via the daughter to the clan of her husband." J. MILGROM, supra note 133, at 482.

137. N. HABEL, supra note 131 , at 585 . Biblical commentators have generally agreed that, according to ancient law, Job's act was unusual. See, e.g., R. GoRDIS, THE BOOK of Job 498 (1978); E. Heaton, The Hebrew Kingdoms 358 (1968); M. Pope, The ANCHOR BIBLE: JOB 292-93 (1965); V. REICHERT, JOB 222 n.15 (1946 \& 7th impression 1970); H. ROWLEY, Јов $268 \mathrm{n} .15$ (2d ed. 1978). The commentators also seem to assume that the daughters actually inherited from Job. For a different view, see J. Milgrom, supra note 133, at 483, arguing that "although Job's daughters inherit with his sons, ... it should not go unnoticed that this is not really a case of inheritance: 'Their father gave them estates together with their brothers' in his lifetime."

138. For discussion of the disappearance of primogeniture in the United States generally, see C. Shammas, M. Salmon \& N. Dahlin, supra note 92 , at 32-35, and M. SALMON, supra note 19 , at 7, 142-43, 227 n.5.

139. Though the practice continued of passing land to sons, the family farm over time, for demographic reasons, tended to go to a younger son rather than the eldest son. See H. Barron, Those Who Stayed Behind: Rural Society in Nineteenth-Century New England 92-98 (1984); R. Gross, The Minutemen and THEIR WORLD 181, 234-35 n.21 (1976). 
of married women and their property was fixed in a system of inequality. Job, after all, had treated his daughters equally with his living sons.

In articulating a simple, but profound, moral vision based on equality, Keziah Kendall aligned herself with a contemporary "equalitarian feminist view." 140 Although Kendall hesitated to accept all the logical consequences of her premise of equality - she personally had no desire to be a representative, a constable, or a sheriff-her feminism was, nevertheless, quite radical for her time. She firmly rejected Greenleaf's argument that women should rejoice in the advantages and protections of their separate sphere, with legal rights "equal, but not identical" to men. As much as Greenleaf revered the cult of domesticity, she, like some feminists of her time, renounced it. But she was different, too, from most "equalitarian feminists" of her time.

Historian Nancy Cott has argued that by 1835 "a minority of women" had begun "to see and protest those boundaries" that "encourag[ed] women to claim a social role according to their sex and to share both social and sexual solidarity. ..."141 It was these "dual bonds of womanhood ... [which] prompted the reappearance of the equalitarian feminist view. ..." ${ }^{142}$ Cott has acknowledged that "[w]hat precipitated some women and not others to cross the boundaries from 'woman's sphere' to 'woman's rights' is not certain. ..."143 But Cott has suggested "that variation on or escape from the containment of conventional evangelical Protestantism ... often led the way."' 144 The story of Keziah Kendall, as told through her letter to Simon Greenleaf, presents an alternative, yet complementary, view of how one woman managed to "cross the boundar[y]" between the ideology of separate spheres and the ideology of equal rights. ${ }^{145}$

140. Nancy Cott used the phrase, "equalitarian feminist view," to describe the late eighteenth-century ideology found in "Mary Wollstonecraft's Vindication of the Rights of Women, ... . and probably best represented in New England by 'Constantia'... . [which] stressed women's common humanity with men and their equal endowment with mental and moral powers; ... [and] denied no venture to women categorically because of their sex." N. CoTT, supra note 59, at 202. See also Basch, Equity vs. Equality: Emerging Concepts of Women's Political Status in the Age of Jackson, 3 J. EARLY REPUBLIC 297 (1983).

141. N. CoTT, supra note 59, at 204.

142. Id.

143. $I d$.

144. Id.

145. Elizabeth Clark has perceptively discussed "women's complex relationship to the American rights tradition." She notes that

[e]arly documents addressed to legislators predictably plead in a secular language of rights based on equality and the revolutionary settlement, commonly citing 
It is true that Kendall's personal religious beliefs contributed to her views on the legal rights of the sexes. Her own particular version of Christianity included a straightforward invocation of the "golden rule," as well as a Job-like acceptance of a capricious God who could take the life of a good man at sea. But unlike Sarah Grimké who painstakingly translated original biblical texts in order to prove that women were equal to men according to the scriptures, Keziah Kendall needed only one fundamental Christian rule and her own life experiences to arrive at equalitarian feminism. And, her life experiences set her apart from most women of her age.

Her personal history, the material conditions of her life, and the structural roles which she assumed in both her family and the market not only made her unique, but also shaped her ethical sensitivity. Because of the twists of fate and the burdens of arbitrary legal rules, she had never married by the age of thirty-two. Yet she was no poor "spinster," but an autonomous, economically independent, and successful land owner and dairy farmer. Within her household, she had assumed many of the traditional male roles, managing the business and watching over the family property, while her older sister, Jemima, who "never had any head for business," performed the domestic chores usually assigned to women. ${ }^{146}$ As a daily actor in the marketplace, she was motivated by "the spirit of self-interest," if not "self-aggrandizement," which characterized the competitive world of men. ${ }^{147}$ Neither captured nor em-

principles like "no taxation without representation." Female lobbyists occasionally invoked their duties as mothers in favor of their cause, but by and large their arguments were couched in the familiar phrases of the revolutionary settlement. Women's writing to women proved a far richer admixture, not limited to claims for political and legal rights, but seeking a range of economic, domestic and personal entitlements and opportunities. Religious language and imagery permeates their discourse, while arguments from liberal theology undergird their vision of total reform.

Clark, Religion, Rights, and Difference in the Early Woman's Rights Movement, 3 WIS. WOMEN's L.J. 29, 44 (1987). Keziah Kendall seems not to fall exclusively within either of Clark's categories. Rather, in the process of rejecting Greenleaf's evangelical persuasion, Kendall seems to draw upon the two modes of discourse identified by Clark.

146. Jemima and Keziah seemed to have divided their household and market tasks according to their interests and abilities, and Keziah described her sister as "a very good manager in the house." This was very different from a typical farm household where roles most often would have been assigned on the basis of sex and would have had hierarchical implications.

147. N. Cotr, supra note 59 , at 70 . Cott uses the quoted phrases to describe men's sphere - the competitive market-in opposition to women's domestic "disinterested" sphere. 
braced by the "bonds of womanhood," she stood outside of them entirely.

From her perspective as a woman not in woman's sphere, Kendall listened to and rejected the logic of Greenleaf's rule-bound world. Intuitively she believed that it was fair results in people's lives that mattered, and not just theories or abstractions. Greenleaf, however, deploying reason in service of faith, both used legal rules as evidence of the caring quality of Christianity and Christianity as a justification for the correctness of legal rules. ${ }^{148}$. Kendall never lost sight of the fact that it was the way legal rules worked that was the real measure of their rightness. Certainly, in her own life, the rules had made a difference, forcing a painful choice between romantic love and economic security. ${ }^{149}$

"Unterrestrial and strong"- this "daughter" of Job rose above her suffering to offer a "small monument" to the integrity of her life. ${ }^{150}$ Keziah Kendall's letter to Simon Greenleaf did more than cross, quietly and privately, the chasm between a Massachusetts dairy farmer and a Harvard law professor, between women and men, between reality and theory. It left a trace, only recently discovered, of one woman's life of courage and pain. She asked only that men treat women on God's earth as Job had treated his daughters in God's kingdom.

\section{DOCUMENT}

Keziah Kendall to Simon Greenleaf ${ }^{151}$

I take the liberty to write to you on the subject of the Lyceum lecture you delivered last Feb. ${ }^{152}$ but as you are not acquainted with me I think I will introduce myself. My name is Kezia Kendall. I live not many miles from Cambridge, on a farm with two sisters, one older, one

148. The tension between reason and faith, within the broader context of the relationship between law, science, and religion, was a theme of some significance in Greenleaf's life. For example, at the same time he was preparing in the 1840 s his monumental three-volume treatise on the law of evidence, he was also working on An Examination of the Testimony of the Four Evangelists by the Rules of Evidence Administered in Courts of Justice, with an Account of the Trial of Jesus, finally published in 1846.

149. See N. CotT, supra note 59 , at $80-83$, for a discussion of the "marriage trauma," which resulted from "[y]oung women's awareness of the conflict between romantic and economic elements in the marriage choice."

150. J. UNTERMEYER, supra note 1 , at 13.

151. The letter has been transcribed as written. All peculiarities of punctuation, spelling, capitalization, and grammar have been retained.

152. The year was probably 1839 . See supra note 5 and accompanying text. 
younger than myself. I am thirty two. Our parents and only brother are dead-we have a good estate-comfortable house-nice barn, garden, orchard \&c and money in the bank besides. Jemima is a very good manager in the house, keeps everything comfortable - sees that the milk is nicely prepared for market-looks after everything herself, and rises before day, winter and summer, - but she never had any head for figures, and always expects me to keep all accounts, and attend to all business concerns. Keranhappuck, (who is called Kerry) is quite young, only nineteen, and as she was a little girl when mother died, we've always petted her, and let her do as she pleased, and now she's courted. Under these circumstances the whole responsibility of our property, not less than twenty five thousand dollars rests upon me. I am not over fond of money, but I have worked hard ever since I was a little girl, and tried to do all in my power to help earn, and help save, and it would be strange if I did not think more of it than those who never earned anything, and never saved anything they could get to spend, and you know Sir, there are many such girls nowadays. Wellour milkman brought word when he came from market that you were a going to lecture on the legal rights of women, and so I thought I would go and learn. Now I hope you wont think me bold when I say, I did not like that lecture much. I dont speak of the manner, it was pretty spoken enough, but there was nothing in it but what every body knows. We all know about a widow's thirds, ${ }^{153}$ and we all know that a man must maintain his wife, and we all know that he must pay her debts, if she has any - but I never heard of a yankee woman marrying in debt. What I wanted to know, was good reasons for some of those laws that I cant account for. I do hope if you are ever to lecture at the Lyceum again, that you will give us some. I must tell my story to make you understand what I mean. One Lyceum lecture that I heard in C. stated that the Americans went to war with the British, because they were taxed without being represented in Parliament. ${ }^{154}$ Now we are

153. She is, of course, referring to a widow's dower rights, which, according to Greenleaf, "entitled [her], by the common law, to the use, for her life, of one third part of all the improvable lands, houses, or other real property which [her husband] owned at any time during the marriage, whether sold by him or not." Greenleaf, supra note 13 , at 285 .

154. Kendall may have been referring to a lecture by Jared Sparks, former owner and editor of the North American Review, who assumed a history professorship at Harvard in 1839. Sparks delivered a lecture at the Salem Lyceum in the 1838-39 season on one of his life's obsessions, the "Causes of the American Revolution." H. OLIVER, supra note 5, at 43. It is possible that Sparks, like Greenleaf, gave his talk at more than one lyceum. 
taxed every year to the full amount of every dollar we possess - town, county, state taxes - taxes for land, for movables, for money and all. Now I dont want to go representative or any thing else, any more than I do to be a "constable or a sheriff," but I have no voice about public improvements, and I dont see the justice of being taxed any more than the "revolutionary heroes" did. You mention that woman here, are not treated like heathen and Indian women-we know that-nor do I think we are treated as Christian women ought to be, according to the Bible rule of doing to others as you would others should do unto you. I am told (not by you) that if a woman dies a week after she's married that her husband takes all her personal property and the use of her real estate as long as he lives ${ }^{155}$ - if a man dies his wife can have her thirdsthis does not come up to the Gospel rule. Now the young fellow that is engaged to our Kerry, is a pleasant clever fellow, but he is not quite one and twenty, and I dont s'pose he ever earned a coat in his life. Uncle told me there was a way for a woman to have her property trustee'd, ${ }^{156}$ and I told it to Kerry - but she, poor girl has romantic

155. Kendall was correct in her understanding of a husband's rights in his wife's personal property if she should die as early as "a week after she's married." But she was only partially correct about the common law rule regarding a husband's interests, as a widower, in his wife's real property. Greenleaf described this rule as follows: "If he survives her, and she has borne him a living child, the estate continues in his hands during his life, because he is bound to maintain that child. If not, it goes to her heirs, as though she had remained single." Greenleaf, supra note 13, at 282.

156. This is a reference to the equitable device of placing the woman's property in a trust before marriage for the purpose of avoiding the husband's common law rights in her property as well as protecting it from the husband's creditors. Under the trust agreement, the trustee would be obligated to manage the property for the benefit of the married woman.

The income of trusts generally could be alienated in anticipation of their receipt by the beneficiary (and thus could be reached by creditors). By the nineteenth century, though, some marriage settlements included "restraint on anticipation" clauses, which prevented the beneficiary - the wife- "from converting her equitable right to a future stream of income into a fixed capital sum." Such a "restraint effectively made the trust for married women indestructible. Equity judges enforced the restraint clause soon after its appearance in the late eighteenth century. ... [T] he purpose of the clause was to protect married women's economic interests from the predation of husbands." Alexander, The Transformation of Trusts as a Legal Category, 1800-1914, 5 LAW \& Hist. REv. 303, 321-22 (1987). We are grateful to Greg Alexander for bringing this point to our attention.

Of course, one of the historical issues at stake is the extent to which fathers used marriage settlements as a device to protect dynastic wealth from being squandered by improvident sons-in-law and their creditors. Keziah Kendall, too, seems to have shared some of the dynastic concerns that motivated paternalistic equitable controls over family 
notions owing to reading too many novels, ${ }^{157}$ and when I told her of it, she would not hear of such a thing - "What take the law to keep my property away from James before I marry him - if it was a million of dollars he should have it all." So you see I think the law is in fault here-to tell you the truth I do not think young men are near so careful about getting in debt as girls, and I have known more than one that used their wife's money to pay off old scores. I had a young friend who was without parents, married when she was twenty years old. She had sixteen thousand dollars all in Bank stock. She has lived in a good house, and dressed well since, but I have never known her to have a five dollar bill to give away, ${ }^{158}$ and I know she had an own Aunt sent to the poor-house last year. She is a generous woman and this would not have been if she had her own money. I had rather go to my mantua maker ${ }^{159}$ to borrow twenty dollars if I needed it, than to the richest married woman I know. Another thing I have to tell you - when I was young I had a lover, Jos. Thompson, he went into business in a neighboring town, and after a year or two while I was getting the wedding things - Joe failed, he met with misfortunes that he did not expect, he could have concealed it from me and married, but he did not-he was honorable, and so we delayed. He lived along here two or three years, and tried all he could to settle with his creditors, but some were stiff and held out, and thought by and by we would marry, and they should get my property. Uncle said he knew if we were married, there

property, but even more, she would have wanted Kerry, for reasons of economic independence, to own and manage her own property after marriage.

157. Keziah shared a widely held distrust of romantic novels. In her study of women in the early republic, Linda Kerber has noted "the impact of the enormous proscriptive literature that counseled everyone, but especially women, against reading novels. Young women were thought to be most vulnerable to the attractions of irresponsibility and passion as depicted in novels. ..." L. KERBER, WOMEN OF THE REPUBLIC: INTELLECT AND IDEOLOGY IN ReVOlutionaRy AMERICA 239 (1980). See also F. Cogan, All-AMERICAN GirL: The Ideal of Real WoManhoOd IN Mid-Nineteenth-Century AMERICA 95-96 (1989).

158. Having a five-dollar bill as spending money may have had special significance for married women. Nancy Cott quotes a Cambridge woman writing to her husband in 1836 as saying, "First when I received the $\$ 5$. bill I kissed it, because it seemed to me a proof that my dear Husband did not lose me from his mind as soon as from his sight. ..." N. COTT, supra note 59 , at 70 n. 12 .

159. In the early republic, mantua makers were often economically independent women who, after a "lengthy apprenticeship ... in the art of fashionable dressmaking could hope for a more secure and affluent life.... Experienced dressmakers could both live well and acquire their own stock of dry goods." M. NORTON, LIBERTY'S DAUGHTERS: THE REVOlUTIONARY EXPERIENCE OF AMERICAN WOMEN, 1750-1800, at 141-42 (1980) (giving a description of mantua makers in the late eighteenth century). 
were those who would take my cattle and the improvement of my land. Joseph used to visit me often those years, but he lost his spirits and he could not get into business again, and he thought he must go to sea. I begged him not to, and told him we should be able to manage things in time, but he said no-he must try his luck, and at least get enough to settle off old scores, and then he would come here and live and we would make the best of what I had. We parted-but it pleased God he should be lost at sea. What I have suffered, I cannot tell you. Now Joe was no sailor when I engaged with him, and if it had been a thing known that I should always have a right to keep possession of my own, he need never have gone to sea, and we might have lived happily together, and in time with industry and economy, he might have paid off all. I am one that cant be convinced without better reasons than I have heard of, that woman are dealt with by the "gospel rule." There is more might than right in such laws as far as I can see-if you see differently, do tell us next time you lecture. Another thing-you made some reflections upon women following the Anti's. When the fuss was about Antimasonry, the women did nothing about it, because there were no female masons, and it was none of their business. ${ }^{160}$ Women have joined the Antislavery societies, and why? ${ }^{161}$ women are kept for slaves as well as men - it is a common cause, deny the justice of it, who can! To be sure I do not wish to go about lecturing like the Misses Grimkie, but I have not the knowledge they have, and I verily believe that if I had been brought up among slaves as they were, and knew all that they know, and felt a call from humanity to speak, I should run the venture of your displeasure, and that of a good many others like you. ${ }^{162}$ I told Uncle that I thought your lecture was a onesided thing - and he said, "why Keziah, Squire Greenleaf is an advocate, not a judge, you must get him to take t'other side next time." Now I have taken this opportunity to ask you to give us a remedy for the "legal wrongs" of women,

160. Kendall may have underestimated the role of women in the antimasonic movement. See P. Goodman, Towards a Christian Republic: Antimasonry and the Great Transition In NEW England, 1826-1836, at 80-102, 173-74 (1988). Before moving to Massachusetts in 1833, Greenleaf for many years had been a devoted Mason, rising to the position of Grand Master of the Grand Lodge of Maine in Portland. In 1820 he wrote $A$ Brief Inquiry into the Origin and Principles of Free Masonry.

161. At this time, some women formed separate female antislavery societies. Female participation and membership was often opposed by men in general antislavery societies. See Larry Ceplair's discussion in The Public Years, supra note 7, at 351-52.

162. Kendall is probably referring here to the "Pastoral Letter" issued by the Congregationalist ministers in the summer of 1837 denouncing the public lecturing of the Grimké sisters. An excerpt from the letter appears in id. at 211-12. 
whenever you have a chance. The fathers of the land should look to these things - who knows but your daughter ${ }^{163}$ may be placed in the sad situation I am in, or the dangerous one Kerry is in. I hear you are a good man, to make it certain - do all the good you can, and justify no wrong thing.

Yours with regard Keziah Kendall.

This essay is dedicated to the memory of our friend, Mary Joe Frug, who certainly would have appreciated and understood Keziah Kendall.

Permission to quote and reproduce Keziah Kendall's letter to Simon Greenleaf has been granted by the Harvard Law School Library. In addition, Judith W. Mellins, manuscript associate in the Special Collections Department at the Harvard Law School Library, graciously supplied needed information and assistance.

We would like to acknowledge our deep gratitude to those who helped us in the painstaking and frustrating search for Keziah Kendall: Jerome E. Anderson, reference librarian at the New England Historic Genealogical Society in Boston, Ann Avery in Logan, Utah, and Elizabeth Clark and Laura Pangallozzi in Cambridge, Massachusetts.

We would also like to thank our colleagues who read a draft of this article and contributed valuable suggestions: Greg Alexander, Jerry Auerbach, Elizabeth Clark, David Engel, George Kannar, Linda Kerber, Kathryn Preyer, Ed Purcell, Jack Schlegel, and Rob Steinfeld. Mary Leary provided important research assistance.

This article stems in part from Konefsky's work on a biography of Simon Greenleaf, which has been supported by fellowships from the Guggenheim Foundation, the National Endowment for the Humanities, the American Bar Foundation Program in Legal History, and the William J. Magavern Fellows Fund.

163. Greenleaf had two daughters who survived infancy. The elder, Charlotte Kingman Greenleaf, was born in 1809 and married Samuel Fuller, an Episcopal minister, in 1830. Kendall was probably referring to Greenleaf's younger daughter, Caroline Augusta, born in 1826. In 1839 she was still living at home with her parents. In 1850 she too married an Episcopal clergyman, Andrew Croswell. See J. GREENLEAF, GeneaLOGY OF THE GREENLEAF FAMILY 417-18 (1896). 